\title{
Chorein Sensitive Dopamine Release from Pheochromocytoma (PC12) Cells
}

\author{
Sabina Honisch ${ }^{\mathrm{a}}$ Birgit Fehrenbacher ${ }^{\mathrm{b}}$ Aleksandra Lebedevaa,c Ioana Alesutan ${ }^{\mathrm{a}}$ \\ Tatsiana Castor $^{a}$ Saad Alkahtanid ${ }^{\text {Saud Alarifid }}$ Martin Schaller $^{b}$ \\ Christos Stournaras ${ }^{\mathrm{a}, \mathrm{e}} \quad$ Florian Lang ${ }^{\mathrm{a}}$
}

Department of Physiology a and Dermatology ${ }^{b}$, University of Tübingen, Germany; 'Department of Immunology, Institute of Experimental Medicine, St. Petersburg, Russia; dDepartment of Zoology, Science College, King Saud University, Riyadh, Saudi Arabia; ' Department of Biochemistry,

University of Crete Medical School, Heraklion, Greece

Key Words

Dopamine $\cdot$ Exocytosis $•$ Degranulation $・$ Vesicles $・$ VAMP8

\begin{abstract}
Background: Chorein, a protein supporting activation of phosphoinositide 3 kinase (PI3K), participates in the regulation of actin polymerization and cell survival. A loss of function mutation of the chorein encoding gene VPS13A (vacuolar protein sorting-associated protein 13A) leads to chorea-acanthocytosis (ChAc), a neurodegenerative disorder with simultaneous erythrocyte akanthocytosis. In blood platelets chorein deficiency has been shown to compromise expression of vesicle-associated membrane protein 8 (VAMP8) and thus degranulation. The present study explored whether chorein is similarly involved in VAMP8 expression and dopamine release of pheochromocytoma (PC12) cells. Methods: Chorein was down-regulated by silencing in PC12 cells. Transmission electron microscopy was employed to quantify the number of vesicles, RTPCR to determine transcript levels, Western blotting to quantify protein expression and ELISA to determine dopamine release. Results: Chorein silencing significantly reduced the number of vesicles, VAMP8 transcript levels and VAMP8 protein abundance. Increase of extracellular $\mathrm{K}^{+}$from $5 \mathrm{mM}$ to $40 \mathrm{mM}$ resulted in marked stimulation of dopamine release, an effect significantly blunted by chorein silencing. Conclusions: Chorein deficiency down-regulates VAMP8 expression, vesicle numbers and dopamine release in pheochromocytoma cells.
\end{abstract}

C. Stournaras and F. Lang contributed equally and thus share last authorship. 


\section{SịNAis}

\begin{tabular}{l}
\hline Neurosignals 2015;23:1-10 \\
\begin{tabular}{l|l}
\hline DOI: 10.1159/000442599 & (c) 2015 The Author(s). Published by S. Karger AG, Basel \\
Published onlIne: December 10, 2015 & www.karger.com/nsg
\end{tabular} \\
\hline
\end{tabular}

Honisch et al.: Chorein Sensitive Dopamine Release

\section{Introduction}

Chorein interacts with the phosphoinositide-3-kinase (PI3K)-p85-subunit thus contributing to PI3K activation with subsequent activation of the small $\mathrm{G}$ protein ras-related C3 botulinum toxin substrate 1 (Rac1) and the $\mathrm{p} 21$ protein-activated kinase 1 (PAK), a signaling cascade eventually leading to actin polymerization and fostering cell survival [1-4]. Loss-offunction mutations of the chorein encoding gene VPS13A (vacuolar protein sorting-associated protein 13A) underlies chorea-acanthocytosis (CA), an autosomal recessive disease [5-10] leading to progressive hyperkinetic movement disorder, cognitive dysfunction, behavioral abnormalities, chronic hyperkalemia and erythrocyte acanthocytosis [6, 11]. Knockout of chorein in mice yields erythrocyte shape changes [12], neuronal apoptosis [13] and altered behavior [13].

Chorein is expressed in a variety of further tissues [14-16] and additional chorein sensitive functions include platelet activation [16], endothelial cell stiffness [15] and tumor cell survival [4]. Chorein sensitive disarrangement of several cytoskeletal structures was reported in human fibroblasts isolated from ChAc-patients [17]. In platelets, chorein deficiency decreases the number of intracellular granules and compromises platelet degranulation [16]. The defect is paralleled by decreased expression of vesicle-associated membrane protein 8 (VAMP8), a critical regulator of platelet degranulation [16]. In pheochromocytoma (PC12) cells chorein was observed in the termini of extended neurites and localized in dopamine containing dense-core vesicles [18]. Overexpression of the carboxyterminal fragment of chorein increased $\mathrm{K}^{+}$-induced dopamine release [18].

The present study explored whether chorein deficiency modifies vesicle abundance, dopamine release and VAMP8 expression in PC12 cells.

\section{Materials and Methods}

\section{Cells}

Pheochromocytoma (PC12) cells [19] were grown in RPMI-1640 (Gibco) supplemented with 10\% horse serum, $5 \%$ fetal bovine serum and $1 \%$ penicillin/streptomycin at $37^{\circ} \mathrm{C}$ in a humidified atmosphere containing $5 \% \mathrm{CO}_{2}$.

\section{Silencing of chorein}

PC12 cells were seeded in 6 well plates on a density of $2 \times 10^{5}$ and cultured under standard culture conditions $\left(37^{\circ} \mathrm{C}, 5 \% \mathrm{CO}_{2}\right)$ for $24 \mathrm{~h}$. The cells were subsequently transfected for $72 \mathrm{~h}$ with validated siRNA for VPS13A (chorein) (ID\#s235043, Ambion, Darmstadt, Germany) or with a negative control siRNA (ID\#s4390843, Ambion) using siPORT amine transfection agent (Ambion) according to the manufacturer's protocol. The efficiency of silencing was checked by RT-PCR.

\section{RT-PCR}

For quantitative real-time PCR (RT-PCR) total RNA was isolated from cells using Trifast Reagent (Peqlab, Erlangen, Germany) according to the manufacturer's instructions. Subsequently approximately 2.5 $\mu \mathrm{g}$ of total RNA was reverse transcribed to cDNA using oligo(dT) $)_{12-18}$ primers and SuperScript II reverse transcriptase. To determine transcript levels of chorein and Vamp8, RT-PCR was performed with the BioRadiCycleriQ ${ }^{\mathrm{TM}}$ Real-Time PCR Detection System (Bio-Rad Laboratories) and GoTaqSybr Green Master Mix (Promega). The reaction was applied in a final volume of $20 \mu \mathrm{l}$ containing $2 \mu \mathrm{l}$ of cDNA under following conditions: an initial incubation at $95^{\circ} \mathrm{C}$ for $5 \mathrm{~min}, 40$ cycles at $95^{\circ} \mathrm{C}$ for $15 \mathrm{~s}, 59^{\circ} \mathrm{C}$ for $20 \mathrm{~s}$ and $72^{\circ} \mathrm{C}$ for $30 \mathrm{~s}$. Specificity of the PCR products was verified by melting curve analysis. The subsequent primers were used (5' $\rightarrow 3^{\prime}$ orientation):

Vps13a fw: TCATCCGGAATCTTCTTCCCTAC

Vps13a rev: TGCCACAACTGTCTGTCCAGTA

Vamp8 fw: ATGACCGAGTCAGGAACCTGC

\section{KARGER}


Honisch et al.: Chorein Sensitive Dopamine Release

Vamp8 rev: TCTTGAAGTGTTCAGACGTGGC

Gapdh fw: TGTGAAGGTCGGTGTGAACG

Gapdh rev: ACATACTCAGCACCAGCATCAC

The mRNA levels of the respective genes were normalized to the expression levels of GAPDH in the same cDNA sample. Relative quantification was calculated according to the $2^{-\Delta \Delta C t}$ method [20].

Western Blotting

To quantify protein abundance, cells were washed twice with ice cold PBS and suspended in $100 \mu \mathrm{l}$ icecold RIPA-lysis buffer (Thermo Fisher Scientific) containing protease inhibitor cocktail (Roche, Mannheim, Germany). The protein concentration was determined using the Bradford assay (BioRad, München, Germany). Forty $\mu \mathrm{g}$ of protein were solubilized in sample buffer at $95^{\circ} \mathrm{C}$ for $5 \mathrm{~min}$ and resolved by $12 \%$ SDSPAGE. For immunoblotting proteins were electro-transferred onto PVDF membranes and blocked with 5\% BSA in TBS- $0.10 \%$ Tween 20 at room temperature for $1 \mathrm{~h}$. Then, the membranes were incubated with either anti-Vamp8 antibody (1:4000, Abcam) or anti-GAPDH antibody (1:2000, Cell Signaling) at $4{ }^{\circ} \mathrm{C}$ overnight. After washing (TBST) the blots were incubated with HRP-conjugated anti-rabbit (1:2000, Cell Signaling) antibody for $1 \mathrm{~h}$ at room temperature. After additional washes (TBST) protein abundance was detected with the ECL detection reagent (Amersham, Freiburg, Germany) and quantified with Quantity One Software (BioRad, Munich, Germany).

\section{Dopamine release}

PC12 cells were silenced for 72 hours and treated with $40 \mathrm{mM} \mathrm{KCl}$ at $37^{\circ} \mathrm{C}$ for 3 minutes to induce dopamine release in the cell culture medium. For determination of dopamine in the cell culture medium a dopamine ELISA kit (IBL International $\mathrm{GmbH}$ ) was used according to the manufacturer's protocol.

\section{Transmission electron microscopy}

After washing with warmed PBS, PC12 cells were fixed with warmed Karnovsky's fixative for $1 \mathrm{~h}$ at RT and stored at $4^{\circ} \mathrm{C}$. For electron microscopic analyses, the cell pellets were embedded in $3.5 \%$ agarose at $37^{\circ} \mathrm{C}$, coagulated at room temperature, and fixed again in Karnovsky's solution. Post-fixation was based on $1.0 \%$ osmium tetroxide containing $1.5 \% \mathrm{~K}$-ferrocyanide in aqua bidest for $2 \mathrm{~h}$. Using standard methods, blocks were embedded in glycide ether and cut using an ultra microtome (Ultracut, Reichert, Vienna, Austria). Ultra-thin sections ( $30 \mathrm{~nm}$ ) were mounted on copper grids and analyzed using a Zeiss LIBRA 120 transmission electron microscope (Carl Zeiss, Oberkochen, Germany) operating at $80 \mathrm{kV}$.

\section{Statistics}

Data are expressed as arithmetic means \pm SEM. Statistical analysis was made by unpaired t-test or MannWhitney test, as appropriate. $\mathrm{p}<0.05$ was considered statistically significant.

\section{Results}

The present study explored whether degranulation of and dopamine release from pheochromocytoma (PC12) cells is sensitive to the presence of chorein. In a first approach, the morphology of the cells was visualized by electron microscopy. As illustrated in Fig. 1, silencing of chorein was followed by a significant decrease of the number of vesicles bound to the cell membrane.

In order to test whether chorein silencing influences degranulation of PC12 cells, dopamine was determined in the supernatant following an increase of extracellular $\mathrm{K}^{+}$from 5 $\mathrm{mM}$ to $40 \mathrm{mM}$. As illustrated in Fig. 2, the amount of dopamine released upon depolarization of the cell membrane was significantly decreased following silencing of chorein.

Additional experiments explored whether the decrease of dopamine release is paralleled by altered expression of vesicle-associated membrane protein 8 (VAMP8). To this end, VAMP8 transcript levels were quantified by RT-PCR. As shown in Fig. 3, the VAMP8 transcript levels were significantly decreased by chorein silencing. 


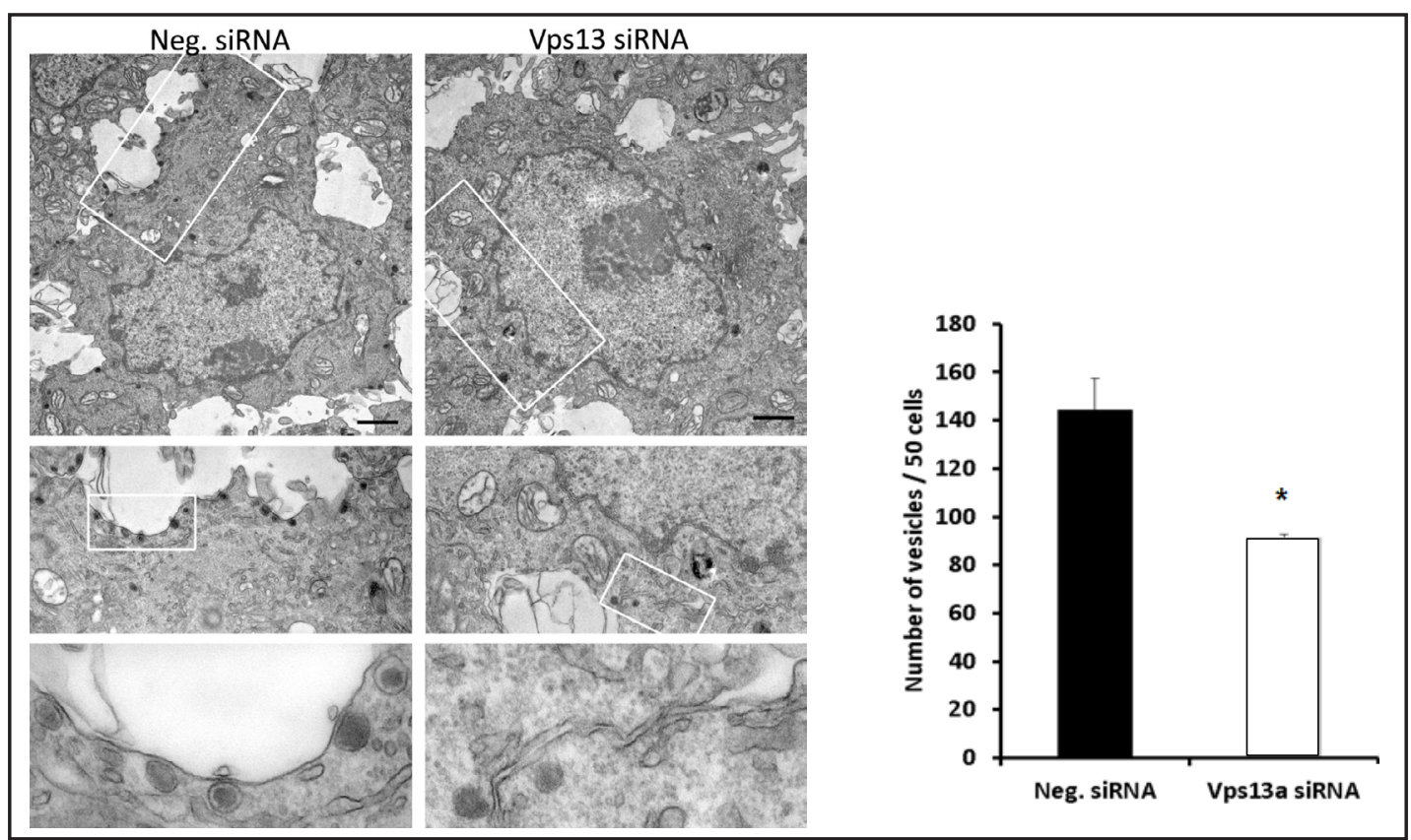

Fig. 1. Chorein sensitive number of vesicles bound to the membranes of PC12 cells. A. Original electron micrograph of pheochromocytoma (PC12) cells following treatment with siRNA without (left panel, Neg. siRNA) and with (right, Vps13 siRNA) specific silencing of chorein. B. Arithmetic means \pm SEM ( $\mathrm{n}=5$ preparations with 50 cells each) of the number of vesicles bound to the cell membrane in PC12 cells treated with unspecific (Neg. siRNA, black bar) and chorein specific (Vps13 siRNA, white bar) silencing RNA. * significant difference $(p<0.05$; t-test).

Fig. 2. Chorein sensitive dopamine release from PC12 cells. Arithmetic means \pm SEM $(n=5)$ of dopamine released following increase of extracellular $\mathrm{K}^{+}$from $5 \mathrm{mM}$ to $40 \mathrm{mM}$ from pheochromocytoma (PC12) cells treated with unspecific (Neg. siRNA, black bar) and chorein specific (Vps13 siRNA, white bar) silencing RNA. ${ }^{* * *}$ significant difference ( $p<0.001$; unpaired t-test).

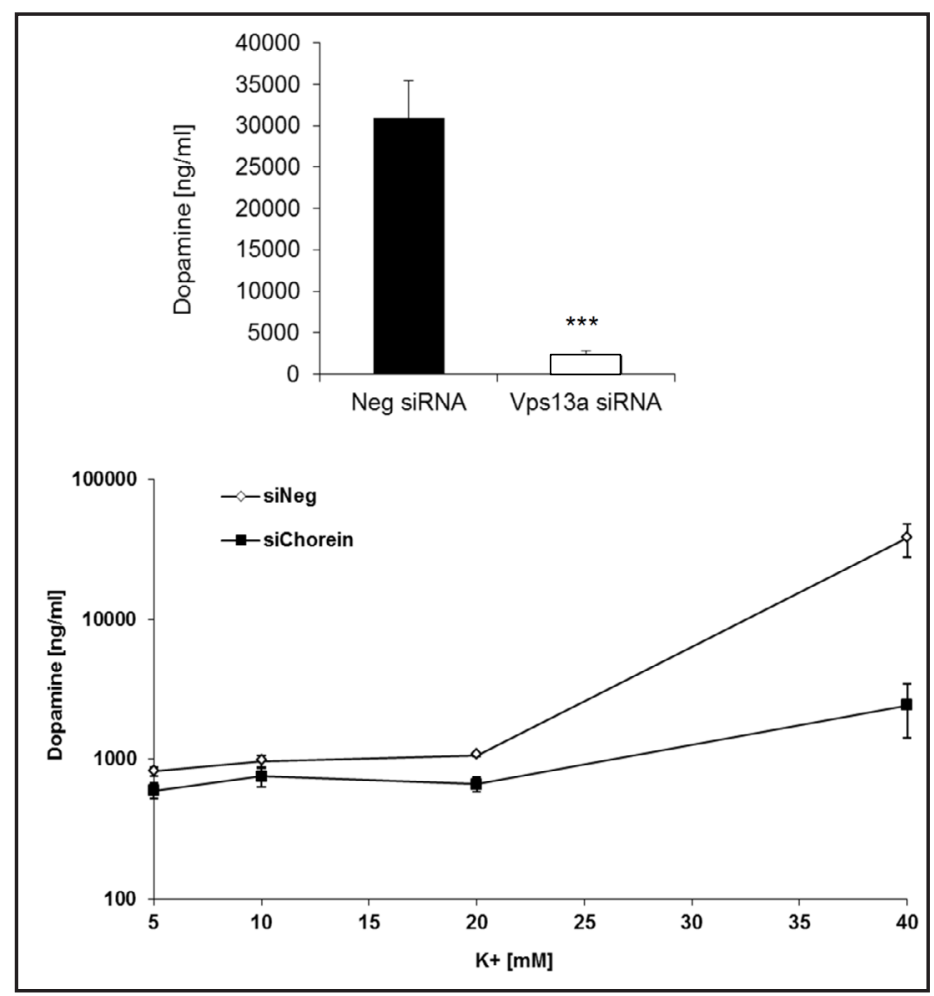

Western blotting was employed to test, whether the decrease of VAMP8 transcript levels following chorein silencing was paralleled by a similar decrease of protein abundance. 
Fig. 3. Chorein sensitive VAMP8 transcript levels in PC12 cells. Arithmetic means \pm SEM $(n=5)$ of transcript levels encoding vesicle-associated membrane protein 8 (VAMP8) in pheochromocytoma (PC12) cells treated with unspecific (Neg. siRNA, black bar) and chorein specific (Vps13 siRNA, white bar) silencing RNA. ${ }^{* *}$ significant difference $(\mathrm{p}<0.01$; unpaired t-test).

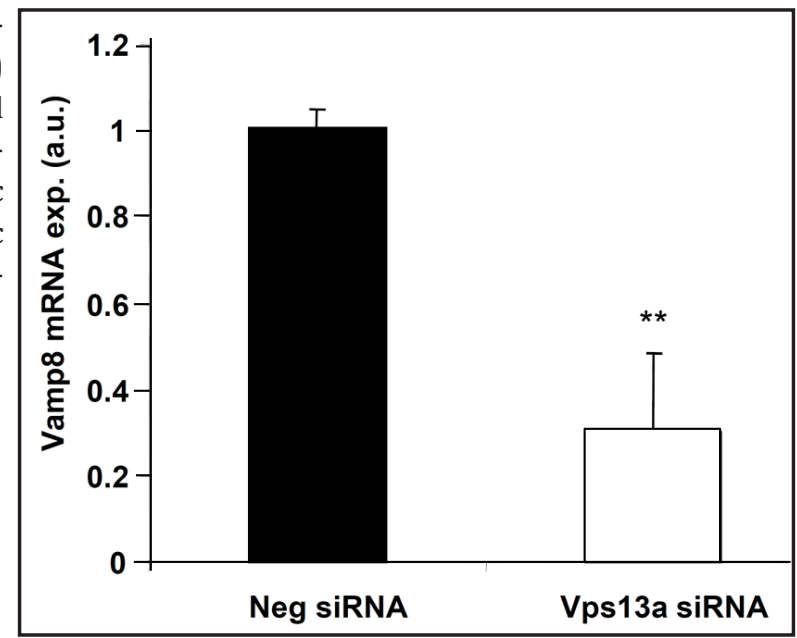

Fig. 4. Chorein sensitive VAMP8 protein expression in PC12 cells. A. Original Western blot showing protein abundance of GAPDH (upper lanes) and vesicle-associated membrane protein 8 (VAMP8, lower lanes) in pheochromocytoma (PC12) cells treated with unspecific (left, control) and chorein specific (right, siChorein) silencing RNA. B. Arithmetic means \pm SEM $(n=5)$ of vesicle-associated membrane protein 8 (VAMP8) in pheochromocytoma (PC12) cells treated with unspecific (Neg. siRNA, black bar) and chorein specific (Vps13 siRNA, white bar) silencing RNA. ${ }^{* * *}$ significant difference $(\mathrm{p}<0.001$; unpaired t-test).

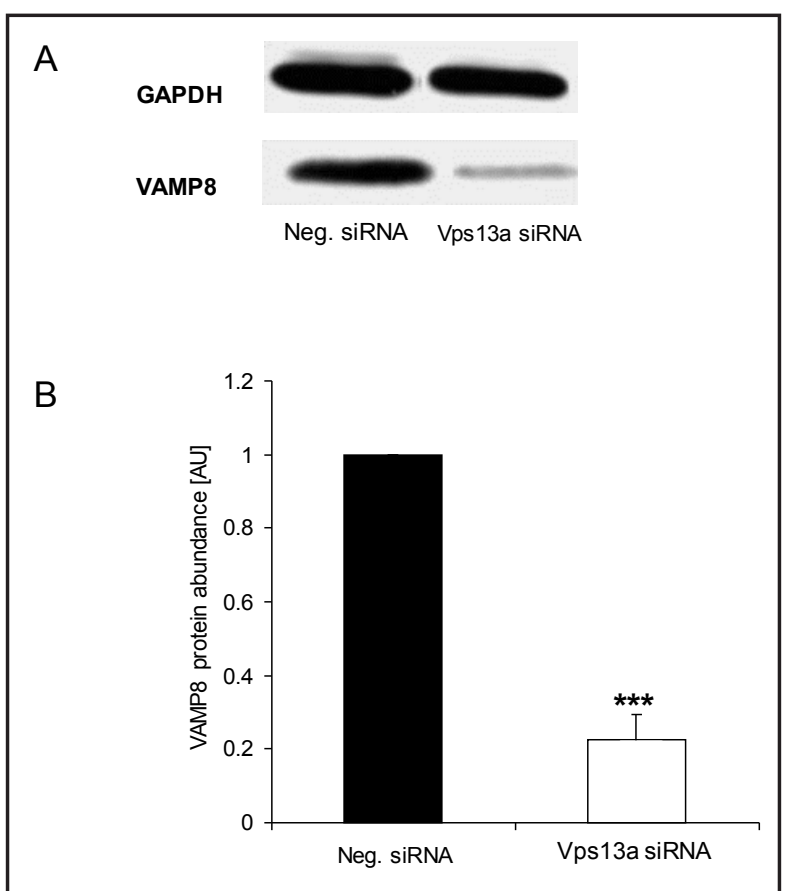

As illustrated in Fig. 4, the VAMP8 protein abundance was significantly lower in chorein silenced PC12 cells than in cells transfected with negative siRNA.

\section{Discussion}

The present study confirms the impact of chorein on dopamine release from pheochromocytoma (PC12) cells [18]. The present observations further reveal that chorein participates in the regulation of vesicle formation. The effect of chorein in PC12 cells is thus similar to the effect in blood platelets. As shown previously [16], in platelets drawn from patients with chorea-acanthocytosis activation-induced platelet secretion from dense granules and alpha granules was significantly less than in platelets drawn from healthy individuals.

The present study further sheds some light on possible mechanisms involved. Similar to what has been observed in megakaryocytes [16], chorein silencing decreases the expression of vesicle-associated membrane protein 8 (VAMP8). The protein is required for granule 
secretion $[21,22]$. VAMP8 forms core SNARE complexes with different partners in different tissues or cell lines [23]. In PC12 cells and NRK cells VAMP8 interacts with syntaxin 7 and 8 , as well as Vtilb [24, 25]. In platelets, VAMP8 targets syntaxin 4 [21]. VAMP8 deficiency compromizes thrombin-induced secretion of blood platelets [26]. Conversely, VAMP8 overexpression results in hyperreactive platelets [27]. In pancreatic acinar cell granule membranes, VAMP8 interacts with syntaxins 2 and 3 as well as SNAP-23 [23]. VAMP8 participates in the formation and is required for fusion of pancreatic acinar cell granules $[23,28]$, which are significantly smaller in VAMP8 knockout mice than in wild type mice [23].

In cytotoxic T cells VAMP8 interacts with Vtib [29], in kidney with syntaxins 3 and 4 [30], in mast cells with SNAP23 and syntaxin 4 [31]. Given the function of VAMP8, the protein is most likely involved in the effects of chorein on degranulation. However, at this stage, we cannot predict to which extent the down-regulation of VAMP8 contributes to the impaired formation of vesicles and/or dopamine release.

The present study did not address the signaling involved in altered VAMP8 expression, vesicle formation and dopamine release following chorein silencing. Chorein has previously been shown to interact with PI3K [1, 2], which is known to participate in the regulation of degranulation in a wide variety of cells [32-40]. Possibly, chorein similarly modifies degranulation of those cells.

PI3K signaling is further known to confer survival of a wide variety of cells including cancer cells [41-55] and neurons [56-59]. Chorein is particularly important for function and viability of neurons and skeletal muscle cells $[6,11]$. Moreover, chorein polymerizes cortical actin filaments $[3,17]$, which is expected to affect a variety of cellular functions including exocytosis [3, 60-69]. Along those lines several cytoskeletal structures including actin microfilaments, microtubules and desmin-, as well as cytokeratin-intermediate filaments are disorganized in human fibroblasts from chorea-acanthocytosis-patients [17]. Interestingly, actin redistribution has been previously described to regulate catecholamine secretion in PC12 cells [70, 71]. However, whether chorein-associated actin cytoskeleton polymerization contributes to the observed chorein sensitive dopamine release in PC12 remains to be elucidated.

In conclusion, the present observations reveal that chorein participates in the regulation of vesicle formation and dopamine release, effects which may contribute to the pathophysiology of chorea-acanthocytosis.

\section{Acknowledgements}

The authors acknowledge the meticulous preparation of the manuscript by Tanja Loch and Lejla Subasic and the support during image evaluation by Christina Braunsdorf. This study was supported by the Deanship of Scientific Research at King Saud University (KSU-RGP-018 Program) Riyadh, Saudi-Arabia.

\section{Disclosure Statement}

The authors declare that they have nothing to disclose.

\section{References}

1 IntAct DIfi: [http://www.ebi.ac.uk/intact/pages/interactions/interactions.xhtml?conversationContext=1]. EMBL EBI database 2011; 
Honisch et al.: Chorein Sensitive Dopamine Release

2 Wu C, Ma MH, Brown KR, Geisler M, Li L, Tzeng E, Jia CY, Jurisica I, Li SS: Systematic identification of SH3 domain-mediated human protein-protein interactions by peptide array target screening. Proteomics 2007;7:1775-1785.

-3 Foller M, Hermann A, Gu S, Alesutan I, Qadri SM, Borst O, Schmidt EM, Schiele F, vom Hagen JM, Saft C, Schols L, Lerche H, Stournaras C, Storch A, Lang F: Chorein-sensitive polymerization of cortical actin and suicidal cell death in chorea-acanthocytosis. FASEB J 2012;26:1526-1534.

4 Honisch S, Yu W, Liu G, Alesutan I, Towhid ST, Tsapara A, Schleicher S, Handgretinger R, Stournaras C, Lang F: Chorein addiction in VPS13A overexpressing rhabdomyosarcoma cells. Oncotarget 2015;6:1030910319.

5 Mohiddin SA, Fananapazir L: Systolic compression of epicardial coronary and intramural arteries in children with hypertrophic cardiomyopathy. Tex Heart Inst J 2002;29:290-298.

6 Dobson-Stone C, Rampoldi L, Bader B, Velayos BA, Walker RH, Danek A, Monaco AP: Chorea-Acanthocytosis. Gene Rev 1993; updated 2010.

7 Dobson-Stone C, Danek A, Rampoldi L, Hardie RJ, Chalmers RM, Wood NW, Bohlega S, Dotti MT, Federico A, Shizuka M, Tanaka M, Watanabe M, Ikeda Y, Brin M, Goldfarb LG, Karp BI, Mohiddin S, Fananapazir L, Storch A, Fryer AE, Maddison P, Sibon I, Trevisol-Bittencourt PC, Singer C, Caballero IR, Aasly JO, Schmierer K, Dengler R, Hiersemenzel LP, Zeviani M, Meiner V, Lossos A, Johnson S, Mercado FC, Sorrentino G, Dupre N, Rouleau GA, Volkmann J, Arpa J, Lees A, Geraud G, Chouinard S, Nemeth A, Monaco AP: Mutational spectrum of the CHAC gene in patients with chorea-acanthocytosis. Eur J Hum Genet 2002;10:773-781.

8 Dobson-Stone C, Velayos-Baeza A, Filippone LA, Westbury S, Storch A, Erdmann T, Wroe SJ, Leenders KL, Lang AE, Dotti MT, Federico A, Mohiddin SA, Fananapazir L, Daniels G, Danek A, Monaco AP: Chorein detection for the diagnosis of chorea-acanthocytosis. Ann Neurol 2004;56:299-302.

9 Ueno S, Maruki Y, Nakamura M, Tomemori Y, Kamae K, Tanabe H, Yamashita Y, Matsuda S, Kaneko S, Sano A: The gene encoding a newly discovered protein, chorein, is mutated in chorea-acanthocytosis. Nat Genet 2001;28:121-122.

10 Tomiyasu A, Nakamura M, Ichiba M, Ueno S, Saiki S, Morimoto M, Kobal J, Kageyama Y, Inui T, Wakabayashi K, Yamada T, Kanemori Y, Jung HH, Tanaka H, Orimo S, Afawi Z, Blatt I, Aasly J, Ujike H, Babovic-Vuksanovic D, Josephs KA, Tohge R, Rodrigues GR, Dupre N, Yamada H, Yokochi F, Kotschet K, Takei T, Rudzinska M, Szczudlik A, Penco S, Fujiwara M, Tojo K, Sano A: Novel pathogenic mutations and copy number variations in the VPS13A Gene in patients with chorea-acanthocytosis. Am J Med Genet B Neuropsychiatr Genet 2011;156:620-631.

11 Saiki S, Sakai K, Murata KY, Saiki M, Nakanishi M, Kitagawa Y, Kaito M, Gondo Y, Kumamoto T, Matsui M, Hattori N, Hirose G: Primary skeletal muscle involvement in chorea-acanthocytosis. Mov Disord 2007;22:848-852.

12 Walterfang M, Looi JC, Styner M, Walker RH, Danek A, Niethammer M, Evans A, Kotschet K, Rodrigues GR, Hughes A, Velakoulis D: Shape alterations in the striatum in chorea-acanthocytosis. Psychiatry Res 2011;192:29-36.

13 Tomemori Y, Ichiba M, Kusumoto A, Mizuno E, Sato D, Muroya S, Nakamura M, Kawaguchi H, Yoshida H, Ueno S, Nakao K, Nakamura K, Aiba A, Katsuki M, Sano A: A gene-targeted mouse model for choreaacanthocytosis. J Neurochem 2005;92:759-766.

14 Kurano Y, Nakamura M, Ichiba M, Matsuda M, Mizuno E, Kato M, Agemura A, Izumo S, Sano A: In vivo distribution and localization of chorein. Biochem Biophys Res Commun 2007;353:431-435.

15 Alesutan I, Seifert J, Pakladok T, Rheinlaender J, Lebedeva A, Towhid ST, Stournaras C, Voelkl J, Schaffer TE, Lang F: Chorein sensitivity of actin polymerization, cell shape and mechanical stiffness of vascular endothelial cells. Cell Physiol Biochem 2013;32:728-742.

16 Schmidt EM, Schmid E, Munzer P, Hermann A, Eyrich AK, Russo A, Walker B, Gu S, vom Hagen JM, Faggio C, Schaller M, Foller M, Schols L, Gawaz M, Borst O, Storch A, Stournaras C, Lang F: Chorein sensitivity of cytoskeletal organization and degranulation of platelets. FASEB J 2013;27:2799-2806.

17 Honisch S, Gu S, Vom Hagen JM, Alkahtani S, Al Kahtane AA, Tsapara A, Hermann A, Storch A, Schols L, Lang F, Stournaras C: Chorein Sensitive Arrangement of Cytoskeletal Architecture. Cell Physiol Biochem 2015;37:399-408. 


\section{SIGíNAis}

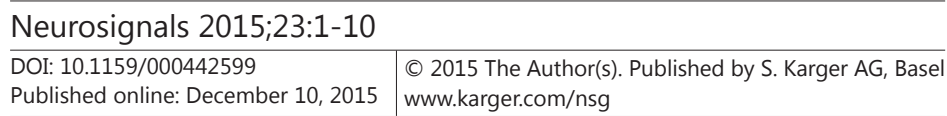

Honisch et al: Chorein Sensitive Dopamine Release

18 Hayashi T, Kishida M, Nishizawa Y, Iijima M, Koriyama C, Nakamura M, Sano A, Kishida S: Subcellular localization and putative role of VPS13A/chorein in dopaminergic neuronal cells. Biochem Biophys Res Commun 2012;419:511-516.

19 Shafer TJ, Atchison WD: Transmitter, ion channel and receptor properties of pheochromocytoma (PC12) cells: a model for neurotoxicological studies. Neurotoxicology 1991;12:473-492.

20 Yang W, Nurbaeva MK, Schmid E, Russo A, Almilaji A, Szteyn K, Yan J, Faggio C, Shumilina E, Lang F: Akt2- and ETS1-dependent IP3 receptor 2 expression in dendritic cell migration. Cell Physiol Biochem 2014;33:222-236.

-21 Polgar J, Chung SH, Reed GL: Vesicle-associated membrane protein 3 (VAMP-3) and VAMP-8 are present in human platelets and are required for granule secretion. Blood 2002;100:1081-1083.

-22 Graham GJ, Ren Q Dilks JR, Blair P, Whiteheart SW, Flaumenhaft R: Endobrevin/VAMP-8-dependent dense granule release mediates thrombus formation in vivo. Blood 2009;114:1083-1090.

23 Hammel I, Wang CC, Hong W, Amihai D: VAMP8/endobrevin is a critical factor for the homotypic granule growth in pancreatic acinar cells. Cell Tissue Res 2012;348:485-490.

24 Antonin W, Holroyd C, Fasshauer D, Pabst S, Von Mollard GF, Jahn R: A SNARE complex mediating fusion of late endosomes defines conserved properties of SNARE structure and function. EMBO J 2000;19:64536464.

25 Antonin W, Holroyd C, Tikkanen R, Honing S, Jahn R: The R-SNARE endobrevin/VAMP-8 mediates homotypic fusion of early endosomes and late endosomes. Mol Biol Cell 2000;11:3289-3298.

-26 Ren Q, Barber HK, Crawford GL, Karim ZA, Zhao C, Choi W, Wang CC, Hong W, Whiteheart SW: Endobrevin/ VAMP-8 is the primary v-SNARE for the platelet release reaction. Mol Biol Cell 2007;18:24-33.

27 Kondkar AA, Bray MS, Leal SM, Nagalla S, Liu DJ, Jin Y, Dong JF, Ren Q, Whiteheart SW, Shaw C, Bray PF: VAMP8/endobrevin is overexpressed in hyperreactive human platelets: suggested role for platelet microRNA. J Thromb Haemost 2010;8:369-378.

28 Messenger SW, Falkowski MA, Groblewski GE: Ca(2)(+)-regulated secretory granule exocytosis in pancreatic and parotid acinar cells. Cell Calcium 2014;55:369-375.

29 Dressel R, Elsner L, Novota P, Kanwar N, Fischer von Mollard G: The exocytosis of lytic granules is impaired in Vti1b- or Vamp8-deficient CTL leading to a reduced cytotoxic activity following antigen-specific activation. J Immunol 2010;185:1005-1014.

30 Wang CC, Ng CP, Shi H, Liew HC, Guo K, Zeng Q, Hong W: A role for VAMP8/endobrevin in surface deployment of the water channel aquaporin 2. Mol Cell Biol 2010;30:333-343.

-31 Paumet F, Le Mao J, Martin S, Galli T, David B, Blank U, Roa M: Soluble NSF attachment protein receptors (SNAREs) in RBL-2H3 mast cells: functional role of syntaxin 4 in exocytosis and identification of a vesicleassociated membrane protein 8-containing secretory compartment. J Immunol 2000;164:5850-5857.

32 Dong J, Lin J, Wang B, He S, Wu C, Kushwaha KK, Mohabeer N, Su Y, Fang H, Huang K, Li D: Inflammatory cytokine TSLP stimulates platelet secretion and potentiates platelet aggregation via a TSLPR-dependent PI3K/Akt signaling pathway. Cell Physiol Biochem 2015;35:160-174.

-33 Fruman DA, Cantley LC: Phosphoinositide 3-kinase in immunological systems. Semin Immunol 2002;14:718.

-34 Fung-Leung WP: Phosphoinositide 3-kinase delta (PI3Kdelta) in leukocyte signaling and function. Cell Signal 2011;23:603-608.

-35 Futosi K, Fodor S, Mocsai A: Reprint of Neutrophil cell surface receptors and their intracellular signal transduction pathways. Int Immunopharmacol 2013;17:1185-1197.

36 Kim MS, Radinger M, Gilfillan AM: The multiple roles of phosphoinositide 3-kinase in mast cell biology. Trends Immunol 2008;29:493-501.

-37 Rivera J, Olivera A: A current understanding of Fc epsilon RI-dependent mast cell activation. Curr Allergy Asthma Rep 2008;8:14-20.

38 Venable JD, Ameriks MK, Blevitt JM, Thurmond RL, Fung-Leung WP: Phosphoinositide 3-kinase gamma (PI3Kgamma) inhibitors for the treatment of inflammation and autoimmune disease. Recent Pat Inflamm Allergy Drug Discov 2010;4:1-15.

-39 Wymann M: PI3Ks-drug targets in inflammation and cancer. Subcell Biochem 2012;58:111-181. 
40 Wymann MP, Bjorklof K, Calvez R, Finan P, Thomast M, Trifilieff A, Barbier M, Altruda F, Hirsch E, Laffargue M: Phosphoinositide 3-kinase gamma: a key modulator in inflammation and allergy. Biochem Soc Trans 2003;31:275-280.

41 Davis NM, Sokolosky M, Stadelman K, Abrams SL, Libra M, Candido S, Nicoletti F, Polesel J, Maestro R, D'Assoro A, Drobot L, Rakus D, Gizak A, Laidler P, Dulinska-Litewka J, Basecke J, Mijatovic S, MaksimovicIvanic D, Montalto G, Cervello M, Fitzgerald TL, Demidenko Z, Martelli AM, Cocco L, Steelman LS, McCubrey JA: Deregulation of the EGFR/PI3K/PTEN/Akt/mTORC1 pathway in breast cancer: possibilities for therapeutic intervention. Oncotarget 2014;5:4603-4650.

42 Ding D, Wei S, Song Y, Li L, Du G, Zhan H, Cao Y: Osthole exhibits anti-cancer property in rat glioma cells through inhibiting PI3K/Akt and MAPK signaling pathways. Cell Physiol Biochem 2013;32:1751-1760.

43 Francipane MG, Lagasse E: mTOR pathway in colorectal cancer: an update. Oncotarget 2014;5:49-66.

44 Fruman DA, Rommel C: PI3K and cancer: lessons, challenges and opportunities. Nat Rev Drug Discov 2014;13:140-156.

45 Hirsch E, Ciraolo E, Franco I, Ghigo A, Martini M: PI3K in cancer-stroma interactions: bad in seed and ugly in soil. Oncogene 2014;33:3083-3090.

46 Hou J, Lam F, Proud C, Wang S: Targeting Mnks for cancer therapy. Oncotarget 2012;3:118-131.

47 Martelli AM, Chiarini F, Evangelisti C, Cappellini A, Buontempo F, Bressanin D, Fini M, McCubrey JA: Two hits are better than one: targeting both phosphatidylinositol 3-kinase and mammalian target of rapamycin as a therapeutic strategy for acute leukemia treatment. Oncotarget 2012;3:371-394.

48 Martini M, De Santis MC, Braccini L, Gulluni F, Hirsch E: PI3K/AKT signaling pathway and cancer: an updated review. Ann Med 2014;10.3109/07853890.2014.9128361-12.

-49 McCubrey JA, Steelman LS, Bertrand FE, Davis NM, Sokolosky M, Abrams SL, Montalto G, D'Assoro AB, Libra M, Nicoletti F, Maestro R, Basecke J, Rakus D, Gizak A, Demidenko ZN, Cocco L, Martelli AM, Cervello M: GSK3 as potential target for therapeutic intervention in cancer. Oncotarget 2014;5:2881-2911.

50 McCubrey JA, Steelman LS, Chappell WH, Abrams SL, Franklin RA, Montalto G, Cervello M, Libra M, Candido S, Malaponte G, Mazzarino MC, Fagone P, Nicoletti F, Basecke J, Mijatovic S, Maksimovic-Ivanic D, Milella M, Tafuri A, Chiarini F, Evangelisti C, Cocco L, Martelli AM: Ras/Raf/MEK/ERK and PI3K/PTEN/Akt/ mTOR cascade inhibitors: how mutations can result in therapy resistance and how to overcome resistance. Oncotarget 2012;3:1068-1111.

51 Ocana A, Vera-Badillo F, Al-Mubarak M, Templeton AJ, Corrales-Sanchez V, Diez-Gonzalez L, Cuenca-Lopez MD, Seruga B, Pandiella A, Amir E: Activation of the PI3K/mTOR/AKT pathway and survival in solid tumors: systematic review and meta-analysis. PLoS One 2014;9:e95219.

52 Rodon J, Dienstmann R, Serra V, Tabernero J: Development of PI3K inhibitors: lessons learned from early clinical trials. Nat Rev Clin Oncol 2013;10:143-153.

-53 Xiao M, Tang Y, Wang YL, Yang L, Li X, Kuang J, Song GL: ART1 silencing enhances apoptosis of mouse CT26 cells via the PI3K/Akt/NF-kappaB pathway. Cell Physiol Biochem 2013;32:1587-1599.

54 Zhang H, Guo M, Chen JH, Wang Z, Du XF, Liu PX, Li WH: Osteopontin knockdown inhibits alphav,beta3 integrin-induced cell migration and invasion and promotes apoptosis of breast cancer cells by inducing autophagy and inactivating the PI3K/Akt/mTOR pathway. Cell Physiol Biochem 2014;33:991-1002.

55 Zhang L, Zhou F, ten Dijke P: Signaling interplay between transforming growth factor-beta receptor and PI3K/AKT pathways in cancer. Trends Biochem Sci 2013;38:612-620.

56 Sedding DG: FoxO transcription factors in oxidative stress response and ageing--a new fork on the way to longevity? Biol Chem 2008;389:279-283.

57 Dudek H, Datta SR, Franke TF, Birnbaum MJ, Yao R, Cooper GM, Segal RA, Kaplan DR, Greenberg ME: Regulation of neuronal survival by the serine-threonine protein kinase Akt. Science 1997;275:661-665.

58 Arboleda G, Morales LC, Benitez B, Arboleda H: Regulation of ceramide-induced neuronal death: cell metabolism meets neurodegeneration. Brain Res Rev 2009;59:333-346.

59 Kreis P, Rousseau V, Thevenot E, Combeau G, Barnier JV: The four mammalian splice variants encoded by the p21-activated kinase 3 gene have different biological properties. J Neurochem 2008;106:1184-1197.

60 Eliyahu E, Tsaadon A, Shtraizent N, Shalgi R: The involvement of protein kinase C and actin filaments in cortical granule exocytosis in the rat. Reproduction 2005;129:161-170.

-61 Keller H, Rentsch P, Hagmann J: Differences in cortical actin structure and dynamics document that different types of blebs are formed by distinct mechanisms. Exp Cell Res 2002;277:161-172. 
62 Malacombe M, Bader MF, Gasman S: Exocytosis in neuroendocrine cells: new tasks for actin. Biochim Biophys Acta 2006;1763:1175-1183.

63 Mitchell T, Lo A, Logan MR, Lacy P, Eitzen G: Primary granule exocytosis in human neutrophils is regulated by Rac-dependent actin remodeling. Am J Physiol Cell Physiol 2008;295:C1354-C1365.

64 Onabajo 00, Seeley MK, Kale A, Qualmann B, Kessels M, Han J, Tan TH, Song W: Actin-binding protein 1 regulates B cell receptor-mediated antigen processing and presentation in response to B cell receptor activation. J Immunol 2008;180:6685-6695.

65 Insall RH, Machesky LM: Actin dynamics at the leading edge: from simple machinery to complex networks. Dev Cell 2009;17:310-322.

66 Papakonstanti EA, Stournaras C: Cell responses regulated by early reorganization of actin cytoskeleton. FEBS Lett 2008;582:2120-2127.

67 Andrade AL, Rossi DJ: Simulated ischaemia induces Ca2+-independent glutamatergic vesicle release through actin filament depolymerization in area CA1 of the hippocampus. J Physiol 2010;588:1499-1514.

68 Stournaras C, Gravanis A, Margioris AN, Lang F: The actin cytoskeleton in rapid steroid hormone actions. Cytoskeleton (Hoboken) 2014;71:285-293.

69 Papakonstanti EA, Vardaki EA, Stournaras C: Actin cytoskeleton: a signaling sensor in cell volume regulation. Cell Physiol Biochem 2000;10:257-264.

70 Charalampopoulos I, Dermitzaki E, Vardouli L, Tsatsanis C, Stournaras C, Margioris AN, Gravanis A: Dehydroepiandrosterone sulfate and allopregnanolone directly stimulate catecholamine production via induction of tyrosine hydroxylase and secretion by affecting actin polymerization. Endocrinology 2005;146:3309-3318.

71 Dermitzaki E, Gravanis A, Venihaki M, Stournaras C, Margioris AN: Opioids suppress basal and nicotineinduced catecholamine secretion via a stabilizing effect on actin filaments. Endocrinology 2001;142:20222031. 